This item was submitted to Loughborough's Research Repository by the author.

Items in Figshare are protected by copyright, with all rights reserved, unless otherwise indicated.

\title{
Social innovations in outsourcing: an empirical investigation of impact sourcing companies in India
}

PLEASE CITE THE PUBLISHED VERSION

http://dx.doi.org/10.1016/j.jsis.2015.09.002

PUBLISHER

(C) Elsevier

VERSION

AM (Accepted Manuscript)

\section{PUBLISHER STATEMENT}

This work is made available according to the conditions of the Creative Commons Attribution-NonCommercialNoDerivatives 4.0 International (CC BY-NC-ND 4.0) licence. Full details of this licence are available at: https://creativecommons.org/licenses/by-nc-nd/4.0/

\section{LICENCE}

CC BY-NC-ND 4.0

\section{REPOSITORY RECORD}

Sandeep, M.S., and M.N. Ravishankar. 2015. "Social Innovations in Outsourcing: An Empirical Investigation of Impact Sourcing Companies in India”. Loughborough University. https://hdl.handle.net/2134/19273. 


\title{
Social innovations in outsourcing: An empirical investigation of impact sourcing companies in India
}

\begin{abstract}
Impact sourcing - the practice of bringing digitally-enabled outsourcing jobs to marginalized individuals - is an important emerging social innovation in the outsourcing industry. The impact sourcing model of delivering Information Technology and Business Process Outsourcing (IT-BPO) services not only seeks to deliver business value for clients, but is also driven by an explicit social mission to help marginalized communities enjoy the benefits of globalization. This dual focus has led to the ambitious claim that social value creation can be integral to (and not always by-products of) innovative IT-BPO models. Given the relative newness of the impact sourcing business model there is scarce research about how impact sourcing companies emerge and the process through which entrepreneurs build and operate such companies. This paper draws on a qualitative study of seven Indian impact sourcing companies and develops a process model of the individual-level motivational triggers of impact sourcing entrepreneurship, the entrepreneurial actions underpinning different phases of venture creation and the positive institutional-level influences on impact sourcing. The paper argues that since deeply personalized values are central to the creation and development of impact sourcing companies, the business model may not be easy to replicate. The analysis highlights an intensive period of embedding and robust alliances with local partners as crucial for the scalability and sustainability of the impact sourcing business model. It also emphasizes the role of 'social' encoding and mimicry in determining the extent to which impact sourcing companies are able to retain their commitment to marginalized communities.
\end{abstract}

Keywords: Impact sourcing, social entrepreneurship, India, social innovation 


\section{INTRODUCTION}

Impact sourcing is an emerging social innovation in outsourcing (Batstone, 2013; Heeks, 2013; Lacity et al., 2014). It is the practice of bringing digitally-enabled outsourcing jobs to marginalized communities. Slowly but surely impact sourcing is being recognized as a socially conscientious way of delivering Information Technology-Business Process Outsourcing (IT-BPO) services (Gino and Staats, 2012; Heeks, 2013; Madon and Sharanappa, 2013;). In this paper, we focus on impact sourcing companies (and on the entrepreneurs who launch such companies) in India ${ }^{1}$. These companies combine the business logic of traditional IT-BPO vendors and the prosocial logic of charitable institutions (Heeks, 2013). The impact sourcing model is innovative in that it provides a novel template for organizing IT-BPO activities by reconfiguring the traditional IT-BPO model into a “socioeconomic hybrid” (Battilana and Dorado, 2010) model; in the impact sourcing model “social value creation” is a consciously stated, long-term intent of the entrepreneur(s) and not merely a by-product of the company's commercial orientation. In other words, impact sourcing belongs to a class of strategic innovations that aspire to squarely address social problems through business venturing. There are suggestions in the extant literature that the impact sourcing model has tremendous potential to foster socioeconomic development in the global south (Madon and Sharanappa, 2013) and positively impact the lives of marginalized communities (Carmel et al., 2013; Heeks and Arun, 2010; Lacity et al., 2014; Madon and Sharanappa, 2013; Malik et al., 2014).

In their quest to create both business and social value, impact sourcing entrepreneurs deviate in some fundamental ways from the established norms and prevailing logics governing mainstream IT-BPO models. Generally, new models of organizing face the daunting task of mobilizing resources, countering critics, and establishing legitimacy and

\footnotetext{
${ }^{1}$ Appendix A provides a broader overview of organizations engaged in impact sourcing.
} 
credibility (Aldrich and Fiol, 1994; Maguire et al. 2004). Likewise, impact sourcing entrepreneurs face the uphill task of building and operating impact sourcing companies in an environment where potential clients are still unsure about the value proposition of impact sourcing (Accenture, 2011; Heeks, 2013) and marginalized communities are wary about the motives of impact sourcing companies (Sinkovics et al., 2014). A limited body of research has looked into the impact of impact sourcing on marginalized individuals (e.g. Heeks and Arun, 2010; Lacity et al., 2014; Malik et al., 2014; Madon and Sharanappa, 2013), the positioning of impact sourcing companies within marginalized communities (e.g. Sandeep and Ravishankar, 2015) and the value proposition of impact sourcing for potential clients (e.g. Accenture 2011). However, given that impact sourcing is a relatively new phenomenon there are still notable gaps in the literature. In this paper, we aim to address two of these gaps. First, there is very little research into the motivational underpinnings of impact sourcing entrepreneurship. A better understanding of the individual-level motivational triggers can provide crucial insights into the early stages of impact sourcing venture creation and the contextual conditions that support (and constrain) the development of impact sourcing entrepreneurship. Second, the process through which entrepreneurs build and operate impact sourcing companies has not yet been explored in any great depth. A process-based view of the development of impact sourcing companies can potentially throw light on the key challenges confronting the business model as well as offer a richer conceptualization of how outsourcing can be used as a tool to achieve social innovation. Thus, this paper addresses the following two exploratory questions: (1) What are the individual-level triggers of impact sourcing entrepreneurship and (2) How do impact sourcing entrepreneurs build and operate impact sourcing companies?

To answer these questions we draw on a largely inductive, qualitative study of seven Indian impact sourcing companies. Theoretically, we build on insights from the social 
entrepreneurship literature. This stream of literature is primarily concerned with the entrepreneurial actions of individuals and organizations pursuing dual (social and commercial) objectives (Corner and Ho, 2010; Miller et al., 2012). Thus, it is particularly well-placed to offer potentially relevant insights into the motivations of impact sourcing entrepreneurs and their efforts to build impact sourcing companies.

\section{SOCIAL ENTREPRENEURSHIP}

Broadly, entrepreneurial activities of individuals and organizations that create 'social' value are described as ‘social entrepreneurship’. More specifically, social entrepreneurship can be viewed as a process that involves "the innovative use and combination of resources to pursue opportunities to catalyze social change and/or address social needs” (Mair and Marti, 2006, p. 37). Recognizing the complex and contested nature of social entrepreneurship, Choi and Majumdar (2014) conceptualize it as a "cluster concept" comprising of sub-concepts such as social value creation, social innovation, the social entrepreneur, the social entrepreneurial organization and market orientation. The overtly stated intent of creating social value distinguishes social entrepreneurship from commercial entrepreneurship (Corner and Ho, 2010; Miller et al., 2012). While profit is seen as the prime driver of commercial entrepreneurship, it is the social mission that shapes social entrepreneurship strategies.

Given that principles of social entrepreneurship are at the core of the impact sourcing model, we first review this stream of literature, with a particular focus on the individual level triggers of social entrepreneurship and on the process of building and operating social enterprises.

\section{Individual level triggers of social entrepreneurship}

The social entrepreneurship literature has looked into what motivates or "tips” an 
individual to start social ventures (e.g. Corner and Ho, 2010; Miller et al., 2012; Renko, 2013). One aspect that has received attention is the role played by affect, i.e. feelings and emotions, which induce prosocial behavior in individuals. The most widely researched emotion in this area is compassion, cited as a principal influence of social entrepreneurship (Dees, 1998; Miller et al., 2012). Miller et al. (2012) argue that the “other-orientation”, or the experienced connection to the sufferings of other individuals, affects the cognition and behavior of individual. In response to these heightened feelings of compassion, individuals may choose to pursue prosocial actions. In addition to "positive" emotions such as compassion, there may be whole range of other emotions, including "negative" emotions that may encourage prosocial behavior in individuals (Miller et al., 2012). Negative emotions such as guilt, shame and moral outrage can motivate individuals to change their future behavior to avoid experiencing those feelings again (Ahn et al., 2013). In short, the social entrepreneurship literature suggests that both negative and positive emotions can trigger prosocial behavior in individuals.

\section{The social entrepreneurship process}

While emotions may trigger the initial spark toward social entrepreneurship, the literature suggests that the orchestration of social entrepreneurship happens through an effectuation process (e.g. Corner and Ho, 2010; Perrini et al., 2010). Effectuation processes "take a set of means as given and focus on selecting between possible effects that can be created with that set of means" (Sarasvathy, 2001, p. 245). Effectuation theory describes how social entrepreneurs function in resource-constrained environments. Such environments invariably demand individuals to adopt innovative means and "think out of the box" to overcome constraints and develop contextually-grounded solutions. In the effectuation process entrepreneurs adopt an intuitive decision making mechanism, sometimes overriding what may appear to be rational choices on offer. This does not mean that an effectuation view 
disregards the rational side of decision-making. Indeed, effectuation and rational/economic processes can coexist and complement each other in an entrepreneurial journey of a social enterprise (see Corner and Ho, 2010). In a recent case study of a drug rehabilitation community, Perrini et al. (2010) identified different stages of social entrepreneurship: opportunity identification, evaluation, formalization, exploitation and scaling-up. They suggest that individual and contextual dimensions have an influence on every stage, giving the process a dynamic feel. Similarly, extrapolating from the findings of in-depth case studies, Corner and Ho (2010) suggested that social enterprises begin with a "spark”, or in other words a moment of inspiration, which sets individuals on a path of identifying and developing opportunities to initiate social change; and that there is an element of collective action, i.e. the coming together of interested actors, in the process of developing such ventures. Quite often, social entrepreneurs need to adapt quickly to the particular requirements of a challenging context (Corner \& Ho, 2010; Robinson, 2006). Research suggests that social enterprises either totally immerse themselves in the local context or partner with "locally embedded actors” in order to survive (Jack and Anderson, 2002).

A number of challenges also arise on account of the equal emphasis on the social and the commercial. For example, mobilizing the support of multiple groups with different and often conflicting expectations is a key issue facing social entrepreneurs (Dacin et al., 2011). Further, social enterprises struggle to acquire credibility as their activities rarely conform to existing institutional norms. Some recent research suggests that social enterprises overcome the credibility deficit by cleverly mimicking features of social welfare organizations to highlight the social aspects of the enterprise and imitating features of for-profit institutions to highlight their business orientation (see Pache and Santos, 2013; Battilana et al., 2012). The 'wicked' problems that social entrepreneurs seek to address may require a different kind of business approach, one involving principles of collaboration rather than competition. In the 
process of building a social enterprise, entrepreneurs may have to form alliances with other organizations (Montgomery et al., 2012) and engage in collaborative learning to build on each other’s expertise (Svendsen and Laberge, 2005; Montgomery et al., 2012).

\section{Impact sourcing from a social entrepreneurship perspective}

Impact sourcing work may be viewed as a particular class of activities within the domain of social entrepreneurial action. Impact sourcing companies aim to address the key social problems (e.g., the issue of unemployment) facing marginalized communities. Globally, the Rockefeller Foundation has played a critical role in bringing impact sourcing to mainstream attention (Heeks, 2013). In June 2011, the Foundation initiated the Poverty Reduction through Information and Digital Employment (PRIDE) program. The focus of this program was to promote impact sourcing in the developing countries of Africa and Asia. The foundation commissioned a report through the Monitor Group in June 2011. This report titled "Job creation through the field of impact sourcing" (Monitor, 2011), went on to lay the foundation for impact sourcing discourse. Recent forecasts paint an optimistic picture of the potential of impact sourcing: the promise of creating nearly half a million jobs and generating close to US\$20 billion in revenues by the end of 2015 (Carmel et al., 2013).

If these estimates are to become a reality, the sustainability of impact sourcing companies is crucial; else there is every chance that the model will remain a niche activity (Heeks, 2013). Ironically, the same aspects of impact sourcing that make it innovative also introduce impediments to the process of building and operating impact sourcing companies. The overt social focus of the model may turn away potential clients who might confuse impact sourcing companies for charity organizations (Gino and Staats, 2012). Further, many impact sourcing companies operating in the global south are based in semi-urban and rural locations (NASSCOM, 2014) - a further challenge to convince potential clients that work can 
be carried out from such locations where the institutional and informational infrastructures are known to be less than robust.

The social entrepreneurship literature's focus on the challenges of managing conflicting expectations (Dacin et al., 2011) resonates particularly strongly with impact sourcing operations and is a crucial aspect of achieving organic growth and sustainability. The inherently hybrid nature of the business model may require impact sourcing companies to put up different "acts" for different audiences as a way of coping with the tensions of possessing a dual-identity. Sandeep and Ravishankar (2015) suggest that impact sourcing companies manage skeptical clients and communities by engaging in impression management and by highlighting intrinsically different aspects of their businesses to these two sets of audiences. Social entrepreneurship's insights into the role of collaborative partnerships and its emphasis on extensive involvement in local community issues (Jack and Anderson, 2002) also bears significance to the process of building impact sourcing companies. Indeed, the importance of local partnerships comes through strongly in the extant narrative accounts of impact sourcing companies (e.g. Madon and Sharanappa, 2013). As Sandeep and Ravishankar (2015) note, local collaborations help impact sourcing companies carefully manage marginalized communities that are highly suspicious of 'outside involvement' in their affairs.

In summary, a review of the social entrepreneurship literature suggests that affect at the individual-level drives the launch of social enterprises. It also highlights the role of effectuation in the development of social enterprises. Empirical studies of social entrepreneurs demonstrate the typical strategies they adopt and the problems they face in building their companies. The current small body of impact sourcing research also broadly reflects the points made in the larger social entrepreneurship literature. In the rest of the paper, we develop these arguments further through an in-depth, largely inductive, qualitative 
study of seven Indian impact sourcing companies. As noted earlier the aim is to explore, in detail, the individual-level triggers of impact sourcing entrepreneurship and the process through which impact sourcing entrepreneurs build and operate impact sourcing companies.

\section{RESEARCH METHODS}

We adopted a qualitative multiple case-study approach in the interpretivist tradition (Walsham, 1995). Interpretive approaches begin with the assumption that "access to reality (given or socially constructed) is only through social constructions such as language, consciousness and shared meanings” (Ravishankar et al., 2013, p.392). An interpretive approach therefore seeks to understand the perspectives of the actors constructing the phenomenon and interpreting their actions in situ. Accessing these perspectives invariably involves in-depth study of the phenomenon in the context in which it is embedded (Myers, 1997). Our research aligned naturally with the interpretivist school of thought given the focus on subjectively interpreting informants' socially constructed experiences of impact sourcing entrepreneurship.

\section{Site selection and access}

India presents a good setting for this study as it is home to a number of pioneering impact sourcing companies. The study was initiated in 2012 as part of a bigger project to document the work of Indian impact sourcing companies. Through an initial period of desk research, we identified seven companies which were frequently cited in the Indian print and electronic media as up and coming impact sourcing companies. Three of these companies had won international accolades for their work and their founders had been invited, on more than one occasion, to speak about social entrepreneurship at important practitioner conferences. 
Fortunately, a key contact at NASSCOM Foundation ${ }^{2}$ helped us gain access to these seven impact sourcing companies.

\section{Research context}

In this study we specifically focused on impact sourcing companies seeking to impact youth in villages and small towns. Recent estimates suggest that such impact sourcing companies in India employ around 9000 people (Everest Group, 2014). While these companies are legally incorporated as for-profit enterprises, their business model pays overt attention to the realization of their social mission. Typically, these companies setup delivery centers in rural communities and small towns, from where they provide outsourcing services to both national and international clients. The services offered by these companies range from simple digitization work to more complex projects such as computer-aided design.

\section{Data collection}

We conducted fieldwork at seven impact sourcing companies over a two-year period (Jan 2012 to Jan 2014). Appendix B summarizes each of the seven cases. A total of 48 indepth interviews were conducted across the seven companies (see Appendix C for a list of informants). For the founders, the interview questions focused on the company's origins, their entrepreneurial journey, the challenges they faced and the strategies adopted to overcome them. For the senior management, questions revolved more around issues related to business development, marketing and operations (see Appendix D for the interview protocol). All empirical material from interviews was triangulated whenever possible. The interviews lasted anywhere between 30 minutes to 2.5 hours and were recorded and transcribed. In addition to the interviews, we also observed a number of employees performing their everyday work. We had long informal conversations with several such

\footnotetext{
2 NASSCOM Foundation is the non-profit arm of the National Association of Software and Services Companies (NASSCOM) in India. It represents the interests of impact sourcing companies.
} 
employees as well as with members of the local community. Detailed notes were made at the end of these interactions. In addition to the informants in the seven companies we interviewed two informants (the CEO and a manager) at NASSCOM Foundation many times over the two year period. We also drew on secondary sources of information such as company reports, blogs, websites and social media outlets such as Twitter, Facebook, Youtube feeds, LinkedIn discussion groups, articles in the business press, and government memos.

\section{Data analysis}

Data analysis spanned three stages. In the first stage, for each case, a database was built comprising of empirical material relating to (1) the individual level motivational triggers of the founder(s) and (2) the actions they undertook in developing and operating their companies. In the second stage, a case-by-case analysis of the individual-level triggers and organizational actions was conducted. Pettigrew's (1990) four-level approach for comparative case research informed our data analysis at this stage. In the first step, for each impact sourcing company, an "analytical chronology" was compiled using interview and secondary data. Each analytical chronology described the impact sourcing company’s history, the founder's motivations to start the venture and the actions taken to develop and operate the venture. In the second step, a "diagnostic case” was constructed for each impact sourcing company. Here, the analytical chronologies for the seven cases were reconstituted to squarely focus on the entrepreneurial actions. In the third step, inductive analysis of each diagnostic case was conducted. Here, we went back and forth between the emerging themes and the literature on social entrepreneurship. This process helped us to relate our empirical material to extant social entrepreneurship literature and generate a set of preliminary findings. The outcome of this process was the creation of a "theoretical case" (Pettigrew, 1990). In the 
fourth step of the second stage, building on the theoretical case and preliminary findings for each company, we conducted a cross-case comparative analysis wherein themes and concepts relating to individual cases were compared and analyzed. Finally, in the third stage, we synthesized the outcomes of the first two stages into a process model, which covered the individual-level triggers of impact sourcing entrepreneurship, the process of building and operating impact sourcing companies, and the wider institutional-level influences.

\section{ANALYSIS}

\section{Triggers of impact sourcing entrepreneurship}

Informants explained that their decision to start impact sourcing companies was influenced by intense spiritual experiences and deep religious beliefs, which heightened their sensitivity to 'human suffering' and motivated them to think beyond private profit and material benefits. The spiritual-religious drivers not only compelled them to think about the larger society, but also sustained their commitment to their respective companies:

Nowadays people are intellectually incapacitated to accept anything from their heart because their mind tells them different things...I enrolled into a meditation program and once I was through with it, I had a clearer mental structure - it made my spiritual journey more efficient. Within a month I quit my job...it was that powerful. Suddenly I had an immense sense of clarity...the knife which couldn't even cut through a bloody potato had become so sharp that I could cut through all the shit in my life and get to the essence of what I wanted to do. It was then that I realized that my life had to mean something more than fulfilling my selfish goals. (Co-founder, Company A)

The guru's mission to bring happiness to the suffering people influenced him (the CEO) deeply. There was no turning back once he made a promise to ensure jobs to people in rural areas. He made it his mission to fulfil the promise; it is something that motivates him even to this day. Other people who join us too have a deep sense of faith in the teachings of the guru. We are on a mission to do good. (Manager (HR), Company B)

The founders felt guilty about their "lack of contribution to society". The emotion of guilt has

been described as "the unpleasant emotional state associated with the negative consequences of one’s actions, inactions, circumstances, or intentions” (Ahn, 2013, pp. 225). 
I had always been at the taking end. All my life I've taken from the society. I realized it was time for me to give back ...I had taken enough. You can't help but feel some guilt for all the privileges you enjoy. Especially once you are exposed to the miseries of others. (Founder, Company C)

Sometimes you get this overwhelming feeling...it was the elephant in my head...What am I doing for the society? For a long time I avoided it...I reached a point where I no longer could ignore it and it was then I decided to do something about it. (Founder, Company E)

Guilt was also accompanied by an overwhelming sense of compassion for marginalized communities. Indeed, all seven founders identified compassion as a key trigger for their entrepreneurial journey.

The youth in these rural areas have tremendous potential. They may not have a college education, but they are street smart and pick up stuff quickly given the opportunity... I always wanted to help them - they deserve every opportunity that youth in urban areas have... and so began my journey! (CEO, Company G)

Table 1 below is an overview of the triggers, which underpinned the founders' prosocial action of starting impact sourcing companies. In two cases (Companies $\mathrm{C}$ and $\mathrm{E}$ ) the founders refused to talk about spiritual-religious matters, while in a different case (Company D) the founder did not experience guilt at any stage, but acknowledged the spiritual-religious roots of his entrepreneurial venture and the feelings of compassion which led to its conception.

\begin{tabular}{|l|c|c|c|c|c|c|c|}
\hline \multicolumn{1}{|c|}{ Trigger } & A & B & C & D & E & F & G \\
\hline $\begin{array}{l}\text { Spiritual- } \\
\text { religious }\end{array}$ & $\checkmark$ & $\checkmark$ & NA & $\checkmark$ & NA & $\checkmark$ & $\checkmark$ \\
\hline Guilt & $\checkmark$ & $\checkmark$ & $\checkmark$ & $\times$ & $\checkmark$ & $\checkmark$ & $\checkmark$ \\
\hline Compassion & $\checkmark$ & $\checkmark$ & $\checkmark$ & $\checkmark$ & $\checkmark$ & $\checkmark$ & $\checkmark$ \\
\hline
\end{tabular}

Table 1: Summary of founders' affects across the seven companies

$\checkmark$ : Observed in the case; $\times$ : Not observed in the case; NA: Data not available

\section{Analysis of the process of impact sourcing entrepreneurship}

Our informants had had long successful careers in mainstream IT-BPO companies. But there were no ready-to-use templates or "best-practices" for developing an impact sourcing business model. Thus, they conceived, built and operated their impact sourcing 
companies through what social entrepreneurship scholars have referred to as an ‘experimental, iterative, dynamic, and messy’ process (see Sarasvathy, 2001).

Broadly, the actions underpinning impact sourcing entrepreneurship can be seen as comprising of three phases, namely: (1) ideation, (2) formalization and (3) operationalization. Table 2 below explains the phases and the corresponding actions, which were inductively derived from our analysis of the empirical material.

\begin{tabular}{|c|c|c|}
\hline $\begin{array}{l}\text { Phase of impact } \\
\text { sourcing } \\
\text { entrepreneurship }\end{array}$ & Actions & Meaning \\
\hline \multirow[t]{2}{*}{ Ideation } & Disembedding & $\begin{array}{lll}\text { Overcoming experiential biases } & \text { and } \\
\text { disconnecting from current thinking modes } & \end{array}$ \\
\hline & Embedding & Cognitive immersion in local community issues \\
\hline \multirow{3}{*}{ Formalization } & 'Social' encoding & $\begin{array}{l}\text { Incorporating social ethos in the organization's } \\
\text { design }\end{array}$ \\
\hline & Mimicry & $\begin{array}{l}\text { Imitating features of an established model to } \\
\text { garner credibility }\end{array}$ \\
\hline & $\begin{array}{l}\text { Collaborative } \\
\text { learning }\end{array}$ & $\begin{array}{l}\text { Sharing and learning from other impact sourcing } \\
\text { companies' experiences }\end{array}$ \\
\hline \multirow{4}{*}{ Operationalization } & $\begin{array}{l}\text { Audience } \\
\text { segregation }\end{array}$ & Playing different parts for different audiences \\
\hline & Frame alignment & $\begin{array}{l}\text { Linking some set of audience's values and beliefs } \\
\text { with the work of the impact sourcing company }\end{array}$ \\
\hline & Demythologizing & Dispelling popular myths \\
\hline & $\begin{array}{l}\text { Building } \\
\text { alliances }\end{array}$ & Partnering with organizations for mutual benefit \\
\hline
\end{tabular}

Table 2. Overview of entrepreneurial actions

\section{Ideation phase}

The ideation phase represented a period of cognitive struggles for the founders during which they carefully identified opportunities for social entrepreneurship and thoroughly evaluated the feasibility of operating impact sourcing companies, given their (founders') capabilities and temperaments. The ideation phase was characterized by two key cognitive actions: disembedding and embedding. Disembedding may be defined as the cognitive action of overcoming experiential biases and disconnecting from current thinking modes: 
I had to stop thinking like a manager and start thinking like an entrepreneur...the differences are obvious aren't they...here I was trying to think how I can create something which can help people while sustaining a business while in fact I was so used to thinking only in terms of the number of clients on my portfolio, sales we made every week...it was obviously a big change for me (Co-founder, Company A).

In concert with disembedding were embedding actions. Here, by embedding we mean cognitively immersing oneself in the everyday realities of local communities:

When you are thinking of impacting the lives of someone in a village far away from your reality, you really need to get into their shoes. There are things which are unique to the community, which I cannot even imagine sitting in my apartment. To get a sense of this context we travelled a lot in the villages and interacted with the locals. (Co-founder, Company A).

This approach is widely known as the "land to lab" approach, which emphasizes the importance of being sensitive to local realities. It has been widely argued that innovations that are devised in "labs" first more often than not fail to address local problems. By contrast, the land to lab (or the embedding) approach helped the impact sourcing company's founders get a better sense of the most pressing needs of marginalized local communities:

Initially, we thought of doing something in the education sector. Later on we realized after interacting with people that education was not a problem...there were plenty of vocational training centers in nearby towns...but getting jobs was the biggest problem... we thought why not bring jobs to their homes! (Founder, Company F).

\section{Formalization phase}

The formalization phase gave form and function to the impact sourcing entrepreneurial companies. In this phase, the companies configured their business model and charted out their mission, vision and the core values, which would serve as guiding principles for their companies. There were three key actions underlying the formalization phase 'social' encoding, mimicry and collaborative learning.

'Social' encoding refers to the strong injection of the 'social' into the impact sourcing business models (also see Battilana et al., 2012). In other words, the companies injected the welfare logic - and this went beyond mere verbal expressions of commitment to the social cause - into their hiring policies, business strategies and community engagement: 
When we started out we hardcoded the social purpose into our business model. We took a firm decision to hire from remote communities... we did not want to stop at just providing jobs...to have a more inclusive impact we invested a large portion of our profits toward community development...it is a reflection of our commitment to the mission. This is a promise we are sticking to no matter what. Besides, you cannot do business here without a strong social focus! (Co-founder, Company A).

and

At the senior management level we look for people who are passionate about our cause and who can align themselves to our vision. We look for a clear sense of social purpose...this is important to us (Manager (HR), Company B).

Many informants noted that having a strong social focus was not only important to them personally, but was also imperative to conducting business in marginalized communities. They argued that ingraining social commitment in the early stages helped increase their company's "social performance” in the long run. This 'social' encoding can also be interpreted as a deliberate strategy to avoid drifting from the mission of creating social impact.

Notwithstanding their overt social focus, the seven impact sourcing companies mimicked mainstream IT-BPO companies in some conspicuous ways. We witnessed mimicry at play both in organizational processes as well as in visual aspects such as office infrastructure, layout and design:

If you walk into one of our offices, you shouldn't realize whether you are in a village $300 \mathrm{kms}$ from the city or inside the city. We try to replicate the look and feel of any urban BPO - not just the looks, but our processes and governance mechanisms bear close resemblance to any urban BPO. The familiarity certainly helps during client audits! (Co-founder, Company A).

and

We have all the processes in place...although we haven't had a formal process audit...we comply with the requirements set by ISO 27001:2005 in every manner (Co-Founder, Company G)

Of course, one might argue from a purely business value perspective that impact sourcing companies had no option but to adopt the standard governance structures and processes of the broader IT-BPO sector. However, it was noteworthy that informants showed a reflexive 
awareness of their mimicking actions and emphasized them as essential to look like mainstream IT-BPO models, appease potential clients and investors, and in general, to enhance their own credibility:

Clients worried about security breathe easy when we demonstrate to them that we are no different process-wise from our urban counterparts. (Co-Founder, Company G)

The absence of ready-to-use organizational templates meant that the companies had to learn from each other's experience as they developed their business model. We refer to this process of learning from each other as collaborative learning (Montgomery et al., 2012).

We are all quite new to this business...It always helps to get an idea of sharing experience. When we were still finalizing our business model, I went around the country and visited other impact sourcing BPOs. Many of the challenges we face are similar; it is always a good practice to exchange notes. Even to this day we exchange notes during conferences and seminars (Co-founder, Company B).

and

When it all started, we were a small bunch of people... what united us was a common mission to bring jobs to the underprivileged (Co-founder and CEO, Company D).

Having a common socially oriented goal seemed to make them less secretive than the purely profit-seeking IT-BPO vendors and more open to the idea of sharing experiences with other impact sourcing companies (see Heeks, 2013).

\section{Operationalization phase}

The success of their hybrid business model clearly depends on the extent to which the impact sourcing companies effectively operationalize both the social and the commercial aspects of the business. In operationalizing their strategic intent, the impact sourcing companies engaged with two very diverse audience groups - potential clients who were largely business oriented and local communities who were more concerned about the 'social welfare' dimension. Our informants explained that they took four types of actions to better manage the relationship with their audiences. We have called these: audience segregation, frame alignment, demythologizing and building alliances. Goffman (1959) describes audience segregation as a tactic by which 'the individual ensures that those before whom he 
plays one of his parts will not be the same individuals before whom he plays a different part in another setting' (pp. 57):

We rarely talk about our social agenda with potential clients. Only towards the end do we mention that we work from rural areas. We do not want to send them a confusing signal. For clients, our proposition has to make business sense and that is all that they care about (BDM, Company F).

and

When you meet heads of the community the focus of discussion is how our company can benefit their youth. (Co-founder, Company E).

The above quotes suggest that informants strategically emphasized different aspects (i.e. social and commercial) of their companies to different audiences. This helped them to creatively address the particular concerns of both clients and local communities. Clients were looking for business value; the social angle of impact sourcing did not seem to matter to them much. Similarly, local communities were more worried about their future job prospects. Alongside audience segregation, informants engaged in what can be termed as frame alignment efforts (Snow et al., 1986; Goffman, 1974). While the purpose of audience segregation was to send different key messages to different audiences, frame alignment strategies ensured that these messages were aligned with what their audience was looking for.

Very often we see young girls moving to the cities in search of call center jobs...the families are not happy about this, but necessity drives them to look for opportunities elsewhere... we tell them (the families) that our offices are safe environments where their daughters can come and work...we even welcome the parents to visit our premises (Team Leader, Company C).

This quote illustrates the invoking of a safety frame to connect to the anxieties of parents. The safety frame conveyed the message that women could work locally in a safe environment. In this case, frame alignment refers to the deliberate linkage of the audience's (here, the community's) interests, values and beliefs with the opportunity provided by the impact sourcing company. The companies also framed their work as highly "professional" 
and "competent" in all their formal presentations so as to signal their serious business intent to potential clients and investors. For instance:

Our services provide significant scope for maximizing business value through cost management, operational efficiency and innovation (Company E website).

and

Our leadership team brings a combined 100+ years of experience leading teams of IT professionals working at premier multinational companies (Company G corporate brochure).

Impact sourcing companies also worked proactively to dispel what they claimed were "popular myths" about doing business in rural India. We refer to this type of work as “demythologizing”. Through demythologizing, there has been a sustained effort to portray a more reasonable account of rural India and to blunt some of the more exotic beliefs.

We get the same silly questions. Are there elephants on the road? Are there any roads at all? Do we get electricity? Does the internet work? We systematically break down these notions at every given opportunity... conferences and client meetings are good opportunities to talk about these issues to send the message loud and clear that rural does not mean cheap quality, rural does not mean charity for the poor (Co-founder, Company D).

Since they were handicapped by their liability of newness (Aldrich and Fiol, 1994), impact sourcing companies carefully built alliances with local partners who bolstered the legitimacy of the impact sourcing business model. Company B and Company D provide good illustrations. They failed in their initial attempts to start BPO delivery centers in villages. Because of their image as outsiders they could recruit very few locals as employees. Things got better only after they allied with entrepreneurially minded locals, who were made franchisee owners of the delivery centers and tasked with recruitment:

Frankly, we thought we were doing a great thing by bringing much needed jobs to these communities. But to our surprise in the first year of our operation, the locals did not evince much interest... we never expected this. It was then that we changed our business model to a franchise model (Marketing Manager, Company B).

Similarly, Company A partnered with a local non-profit organization, which implemented social-welfare programs for historically disadvantaged communities and had nearly three decades of experience of working with rural, marginalized communities. This non-profit 
organization helped Company A develop closer links with the local community, manage operations, and hire and train new recruits. In short, impact sourcing companies built alliances with a range of locally embedded actors to gain the trust of the communities they sought to impact.

\section{A cross-case analysis of ideation, formalization and operationalization}

We now present a cross-case analysis, which compares the trajectories of the seven companies through the three phases. Table 3 (below) shows how the actions within the three phases were performed almost universally across the seven cases. However, we found two broad types of variations in the trajectories of the companies. First, there were some differences in terms of whether a company chose to perform a particular action or not. In the process of developing their ventures not all companies undertook all the actions we have described so far (see Table 3 below). For instance, Company F believed they were better off working on their own. They found no trustworthy local partners they could align with. At the time of our fieldwork, Company F had built no local alliances whatsoever and yet it seemed that they were running a reasonably successful impact sourcing operation. Similarly, the founder of Company D believed that the company's social and commercial dimensions needed to be equally emphasized to prospective clients. His beliefs had been strongly

reinforced by clients who had unequivocally told him that they chose Company D as a vendor because they were impressed by its social focus. He also believed that no special marketing and public relations campaigns were needed to convince the local population of the benefits of impact sourcing. Therefore, Company D did not engage in any audience segregation and frame alignment actions (see Table 3 below). 


\begin{tabular}{|l|l|c|c|c|c|c|c|c|}
\hline $\begin{array}{c}\text { Phase of impact } \\
\text { sourcing } \\
\text { entrepreneurship }\end{array}$ & \multicolumn{1}{|c|}{ Action } & A & B & C & D & E & F & G \\
\hline \multirow{3}{*}{ Ideation } & Disembedding & $\checkmark$ & $\checkmark$ & $\checkmark$ & $\checkmark$ & $\checkmark$ & $\checkmark$ & $\checkmark$ \\
\hline & Embedding & $\checkmark$ & $\checkmark$ & $\checkmark$ & $\checkmark$ & $\checkmark$ & $\checkmark$ & $\checkmark$ \\
\hline \multirow{5}{*}{ Formalization } & Collaborative learning & $\checkmark$ & $\checkmark$ & $\checkmark$ & $\times$ & $\checkmark$ & $\checkmark$ & $\checkmark$ \\
\hline & Social' encoding & $\checkmark$ & $\checkmark$ & $\checkmark$ & $\checkmark$ & $\checkmark$ & $\checkmark$ & $\checkmark$ \\
\hline & Mimicry & $\checkmark$ & $\checkmark$ & $\checkmark$ & $\checkmark$ & $\checkmark$ & $\checkmark$ & $\checkmark$ \\
\hline \multirow{5}{*}{ Operationalization } & Audience segregation & $\checkmark$ & $\checkmark$ & $\checkmark$ & $\times$ & $\checkmark$ & $\checkmark$ & $\checkmark$ \\
\hline & Frame alignment & $\checkmark$ & $\checkmark$ & $\checkmark$ & $\times$ & $\checkmark$ & $\checkmark$ & $\checkmark$ \\
\hline & Building alliances & $\checkmark$ & $\checkmark$ & $\times$ & $\checkmark$ & $\checkmark$ & $\times$ & $\checkmark$ \\
\hline & Demythologizing & $\checkmark$ & $\checkmark$ & $\checkmark$ & $\checkmark$ & $\checkmark$ & $\checkmark$ & $\checkmark$ \\
\hline
\end{tabular}

Table 3. Evidence of entrepreneurial actions across cases

$\checkmark$ : Observed in the case $x$ : Not observed in the case

The second type of variation related to the sequencing of the ideation, formalization and operationalization phases. The three phases did not develop in the same linear sequence (i.e. ideation-formalization-operationalization) in all seven cases (see Figure 1 below). Put differently, not every company in our sample seriously considered disembedding and embedding actions (the ideation phase) as an important first step and immersed themselves in such actions before they began operations. Some companies somewhat overestimated the transferability of their prior experiences and abilities to the impact sourcing context. Thus, we found that three companies - B, C and E - pretty much started from the formalization phase. In Figure 1 this is depicted pictorially by the numeral 1 placed in the top right hand corner of the cells corresponding to the formalization phases of companies $\mathrm{B}, \mathrm{C}$ and $\mathrm{E}$ respectively. As the founder of Company $\mathrm{C}$ explained it:

Once we identified the business opportunity, we jumped right in to it. We did not really invest in understanding the local realities or spend too much time figuring out the local politics. We knew we had a lot of experience with outsourcing operations and we were confident that things will eventually work out. We hit the ground running. 


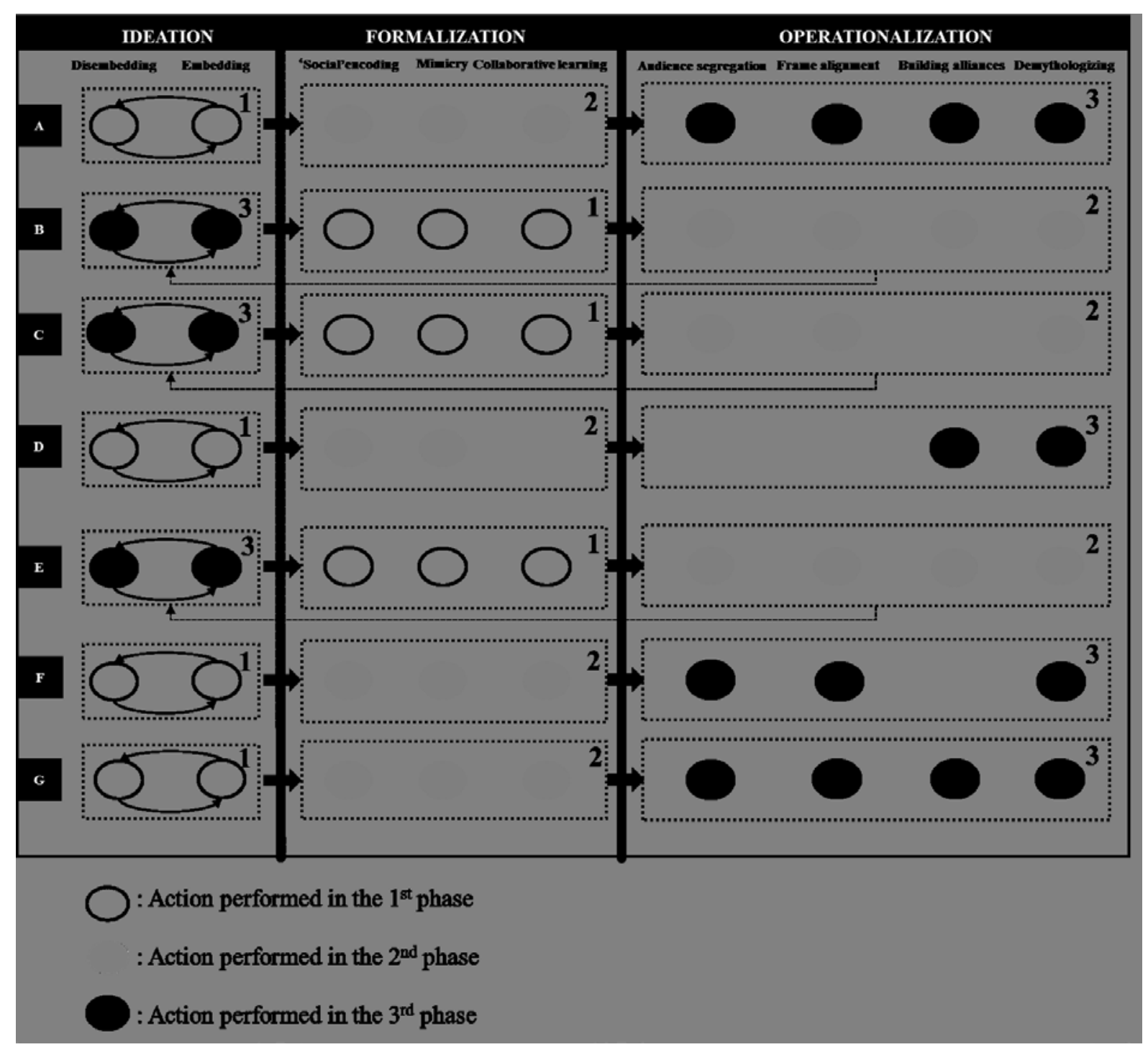

Figure 1: Cross-case analysis

In their second phase of their development, these companies performed actions corresponding to the operationalization phase. In Figure 1 this is depicted pictorially by the numeral 2 placed in the top right hand corner of the cells corresponding to the operationalization phases of companies B, C and E respectively. After they started operations, these companies became aware of the importance of accruing what Khanna (2014) has referred to as "contextual intelligence” (i.e. specific knowledge about the social, political and cultural realities of their particular setting). At this point, the founders started developing a deeper cognitive engagement with local community issues and a sharper awareness of their own biases. In other words, these companies undertook intensive 
disembedding and embedding actions only after they began operations. In Figure 1 this is depicted pictorially by the numeral 3 placed in the top right hand corner of the cells corresponding to the ideation phases of companies $\mathrm{B}, \mathrm{C}$ and $\mathrm{E}$ respectively.

We realized there were many many things we did not know about the community and its way of approaching life. It was very different from our own beliefs. So, relatively later in our entrepreneurial journey we spent a lot of time and effort plunging ourselves into the community (Founder, Company E).

By contrast, the founders of Companies A, D, F and G took a more cautious approach and invested a great deal of energy initially into better understanding their respective local communities. Their deep immersion into the social worlds of the local communities also helped them become more pragmatic in their thinking. Notably, they went through this process before starting their impact sourcing companies. Hence, for these four companies we would argue that the disembedding and embedding actions (the ideation phase) came first, followed by the formalization and operationalization phases respectively (see Figure 1).

For me it was always about getting embedded in the community before starting out. It becomes much easier when you understand and appreciate what is going on locally (Co-founder, Company A).

Overall, this analysis suggests that the two types of variations in the companies' trajectories resulted from differences in contextual conditions (e.g., non-availability of a reliable local partner) and from the different belief systems the founding entrepreneurs subscribed to (e.g., the belief that embedding actions are not really necessary given the current skills and capabilities of the senior management).

\section{DISCUSSION}

The above analysis of seven Indian impact sourcing companies highlights the main individual-level motivational triggers of impact sourcing entrepreneurship. Spiritual-religious experiences and feelings of compassion for marginalized communities underpinned individuals' decision to turn into impact sourcing entrepreneurs. In six of the seven cases in 
our sample, the founders had also experienced a profound sense of guilt for the financial freedom they enjoyed and for the good quality of life they could afford. This feeling of guilt was one of the key emotions spurring them to think of impact sourcing entrepreneurship. Thus, our empirical analysis reinforces claims made in the social entrepreneurship literature about how affect is at the heart of social businesses (Dees, 1998; Miller et al., 2012). Our findings suggests that while the business dimension is central to their scalability and sustainability, the launch of impact sourcing companies may have less to do with marketbased considerations and more to do with individuals' intense personal experiences manifesting into a desire to do social good. In other words, the initial momentum for impact sourcing innovations is more likely to come from individuals' going through an intense period of introspection than from them undertaking a rigorous and objective analysis of business opportunities in the IT-BPO market. The scholarship on the benefits of outsourcing has for long pointed out the tremendous business benefits of operating from low-cost locations in developing countries like India (Apte and Mason, 1995; Contractor et al., 2010; Ravishankar et al., 2013; Vestring et al., 2005). Clearly, impact sourcing entrepreneurs follow this business logic closely. Yet, as our seven cases demonstrate vividly, what these entrepreneurs find attractive in the first instance, are not the business opportunities, but the opportunity to serve marginalized communities. In thinking about their experiences of guilt and concern for the poorer sections of society one could also perhaps point (slightly speculatively) to India's long standing engagement with spirituality and religion as an institutional force that drives impact sourcing.

In some respects, the altruistic roots of impact sourcing companies also chime with the origins of some of the more traditional IT offshoring vendor companies. For instance, the origin of Infosys, perhaps the best known Indian IT services company, is a case in point (see BBC, 2011). The history of Infosys shows that in the early days of its operation, the founders 
were explicitly driven by the social mission of providing jobs to millions of educated Indians struggling to procure gainful employment (see Friedman, 2004; Hindu, 2014). Of course, Infosys is now a global player in the IT-BPO sector and the company swears more by its business goals and less by its social goals. There is every possibility, then, that what starts off as socially-driven impact sourcing company could transform itself and eventually come to be perceived as just any other business organization delivering IT-BPO services to global clients. Based on the findings of our study, we would argue that the extent to which an impact sourcing company is able to retain its commitment to marginalized communities in the long run depends significantly on two of the actions ('social' encoding and mimicry) described in our findings above. It would seem that the more hardwired the 'social' into a company's ethos, the less likely it will compromise on its social commitments. Digital Divide Data (DDD), the impact sourcing company operating from locations such as Cambodia and Kenya provides a good illustration of a firm with a strong 'social' encoding in place (Smith et al., 2012). On the other hand, when a company commits itself to mimicking the mainstream IT-BPO sector in all its governance structures and processes, it may no doubt find itself moving up the value chain. But such a progress could mean that some compromises and trade-offs around social obligations are inevitable. For instance, to perform challenging projects such a company might be compelled to recruit qualified urban graduates instead of their less educated rural counterparts, thus somewhat diluting their 'social mission'.

The empirical material also showed how the seven companies built and operated their impact sourcing companies. The entrepreneurial action guiding the growth of the companies comprised of three phases: ideation, formalization and operationalization. We also identified the key actions contributing to each of the three phases. Notably, there were important variations in how these three phases played out in the seven companies. Some companies chose to go through an extended period of immersion in the local community before they 
formally began operations. Others started their companies first before realizing the importance of being embedded in the local context. For this second category of companies, the ideation (i.e, disembedding and embedding actions) phase came much later in their development. In other words, all seven companies did not go through three phases in the same linear sequence. These findings indicate that impact sourcing entrepreneurs don't follow a specific template for building their companies. In our seven cases a broader effectuation logic (Corner and Ho, 2010; Saraswathy, 2001) guided the social entrepreneurship process. The companies experimented with new ideas, unlearnt old ways of doing, learnt new skills while all the time accumulating what Khanna (2014) recently termed “contextual intelligence”. The companies' trajectories were characterized by dynamism, reflecting the effectuative nature of the social entrepreneurship process. Of course, it was a bigger struggle for those companies that did not immerse themselves in the local context before starting operations. They faced more problems and it took them much longer to stabilize their operations. By contrast, the companies that started from the ideation phase had gone through an intensive initial period of embedding and acquired the kind of local intelligence that allowed them to invest resources (both financial and human) more efficiently. These companies faced fewer challenges in operationalizing the impact sourcing business model.

Although our study creates the impression that impact sourcing innovations have emerged mostly through bottom-up processes (i.e., situated individuals deciding to turn into impact sourcing entrepreneurs), the role played by other actors in the institutional environment cannot be ignored. Social entrepreneurship rarely occurs in a vacuum and is more than just the work of lone, heroic individuals and organizations (Corner and Ho, 2010; Dacin et al., 2011; Montgomery et al., 2012; Spear, 2006; VanSandt et al., 2009). To pursue their social and commercial goals, social entrepreneurs need access to diverse sets of 
resources and skills, many of which they may not possess (Montgomery et al., 2012; Van Sandt et al., 2009). It is here that a broader set of stakeholders, organizations and networks come into the picture and play a crucial role in supporting and enabling the mission of social entrepreneurs and enterprises. In the Indian impact sourcing context, the Rockefeller Foundation, the NASSCOM Foundation and provincial Indian governments (to name three key entities) have worked hard alongside the impact sourcing companies themselves, to build legitimacy and enhance the credibility of the business model, and to empower fledgling startup firms in the sector. For instance, the government of Karnataka in southern India provides start-up grants of approximately US \$32,000 for impact sourcing entrepreneurs (NASSCOM, 2014). More recently, the Indian national government has shown interest in supporting entrepreneurs to set up impact sourcing delivery centers in rural India (Subbu, 2015). Thus, we see actors in the larger institutional environment advocating the idea of impact sourcing, contributing to the mobilization and better organization of impact sourcing ventures, and projecting impact sourcing in a positive frame. We have synthesized these findings and our overall analysis into a process model, which depicts the individual level triggers, the organizational process of building impact sourcing companies and the nature of institutional-level support offered to impact sourcing (see Figure 2 below).

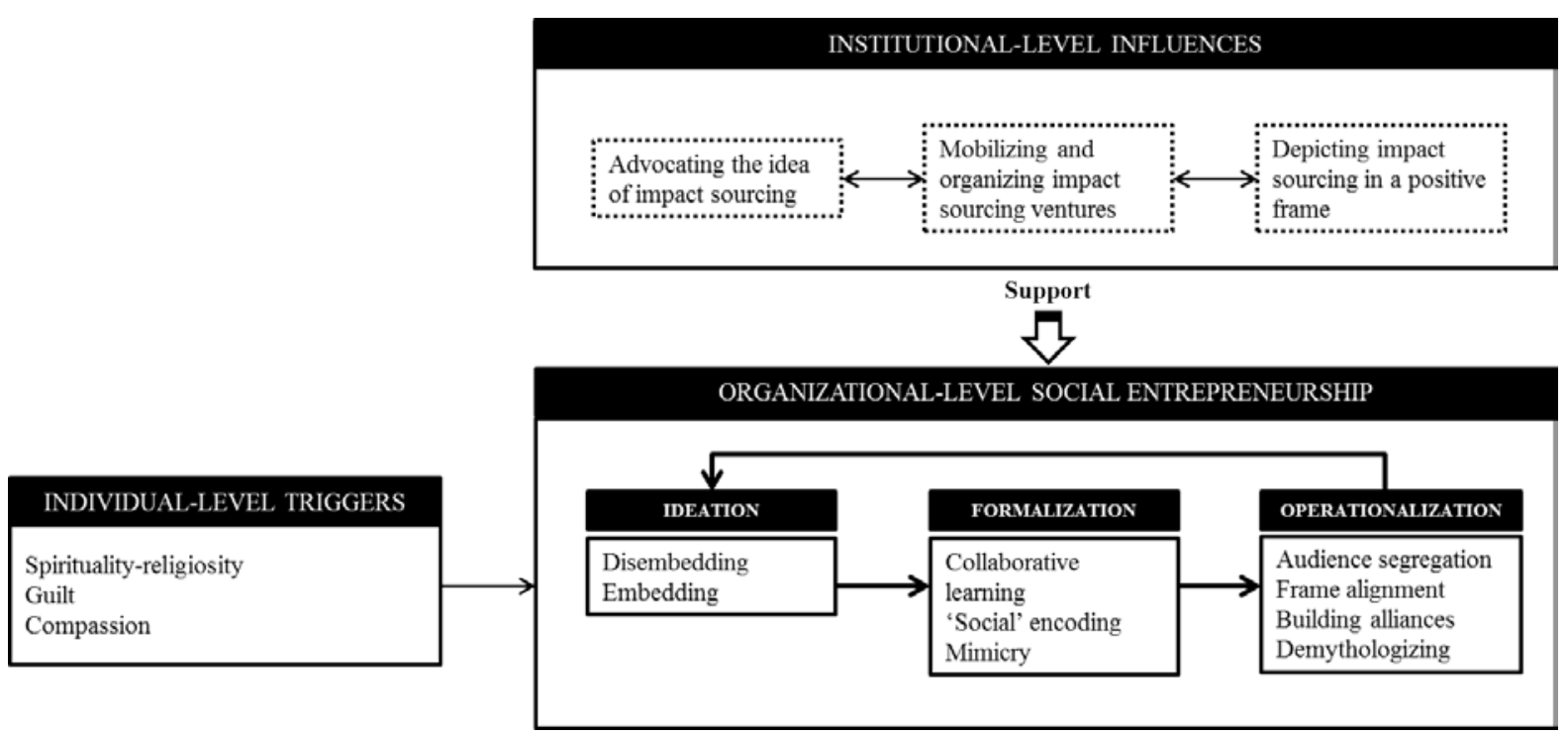




\section{Figure 2: An impact sourcing process model of individual-level triggers, organizational processes and institutional influences}

Contributions to research

This paper highlights several key aspects of the nascent stages of the social entrepreneurship process (Renko, 2013). In particular, it contributes to the small, but growing body of work in the IS literature on impact sourcing innovations (Carmel et al., 2013; Heeks, 2013; Madon and Sharanappa, 2013). The experience of the seven companies we studied provides insights into the contextual conditions nourishing the growth of impact sourcing innovations. Since personal values of the entrepreneurs, rather than quantitative estimates of the overall business value proposition, appear crucial for impact sourcing companies to take shape, mere exhortations by think tanks, lobbying groups and governments may not lead to the anticipated spurt in impact sourcing providers. As we found in our study, impact sourcing entrepreneurs did not really have revenues and profits in mind when they started operations. From a purely business perspective, the individual-level triggers identified in our study can't be described as rational and logical as such. It was their newfound commitment to social causes that got the founders thinking about business venturing and not the other way around. Evidently then, social innovations do not present themselves as neat business opportunities for profit-minded individuals to identify, evaluate and exploit. In fact, it seems opportunities for social innovations become apparent only after deep personal and sometimes spiritual experiences, which guide individuals towards a path of prosocial behavior. Thus, social innovations may be relatively very difficult to "plan" for, as the initial "spark" (Corner and Ho, 2010) or the “calling” can’t be generated through official strictures or policy statements.

For this very reason, impact sourcing innovations may be difficult to replicate in different parts of the world, despite agencies with an international reach such as the Rockefeller Foundation being at the forefront of a concerted global effort to bring impact sourcing to different parts of the developing world (Heeks, 2013). Our study suggests that 
since deeply personalized values of the concerned entrepreneurs hold the key, the impact sourcing business model may not travel all that well. This argument, of course, is neither meant to belittle the efforts of international foundations nor to suggest that such entities should do nothing to support impact sourcing. But it does help place the challenges confronting impact sourcing in its proper context.

The seven cases in our study underscore the significance (for impact sourcing companies) of an extended period of embedding in the local community. Our informants observed that they were able to get the full support of the local people for their business operations only after they immersed themselves into the socio-political affairs of the community. This intimate involvement helped change the community's beliefs about the ‘snobbishness' and 'high-status attitude’ of the impact sourcing entrepreneurs. Well-meaning entrepreneurs may over-estimate the extent to which their cultural background and prior experiences in the IT-BPO sector can help them run an impact sourcing operation from (say) rural India. Sandeep and Ravishankar (2015) document the fundamentally different ideological positions and rhythms of life adopted by some North Indian local communities. For instance, older members of some local communities may have a high say in deciding whether younger members of the community should be allowed employment in impact sourcing companies (p.8). Similarly, community leaders may treat impact sourcing companies as outcasts and deny them access to crucial resources (p.14). Such problems are likely to cause a great deal of frustration for impact sourcing entrepreneurs. Extended periods of embedding may seem like a waste of time given that the activities involved therein are often not directly connected to the core of what the impact sourcing business is about. By contrast, the findings of our study suggest that embedding actually facilitates smoother impact sourcing operations and is potentially an important enabler for the business model's sustainability. 
In the literature on political entrepreneurship there is more than one account of how long periods of immersion helped craft successful political strategy. The most famous example is perhaps Gandhi’s year-long immersion into rural Indian life after his return from South Africa, which helped him generate a groundswell of support and gave impetus to the Indian freedom movement (Brown, 1974). Mohammad Yunus, a leading figure in microfinance, drawing from his own example, suggests that immersing oneself in the local culture is central to the design and implementation of a social business (Yunus, 2010). The crucial implication for impact sourcing companies and for social innovations more generally, is that embedding builds strong social bonds and trust with local communities. In the mainstream management literature, a period of embedding is seen as necessary for the accruing of local or contextual intelligence (Jack and Anderson, 2002). In the context of impact sourcing and social innovations, it would appear that the stakes are a notch higher. Here, embedding is more than just being aware of the local context. The need for contextual intelligence is important, but entrepreneurs also need to break bread with local community leaders and spend what might initially seem like a lot of time getting to know the community and reassuring them of the company's good intentions. As Khanna (2014) emphasizes, the most difficult work for companies is the "softer work" i.e., being more acceptable to new worldviews, changing long held beliefs and tweaking mental models to suit the local context. Getting embedded in the local community could also facilitate disembedding. In other words, immersion can help entrepreneurs unlearn some of their old worldviews and mental models, making way for new knowledge and better collaborative instincts.

Related to the above point, the findings of our study suggest that collaboration with local partners may be central to the successful orchestration of impact sourcing companies’ strategic intent. Informants in five of our case companies explained that they benefitted greatly from the local knowledge and respect their collaborators commanded in the 
community. Two companies could not find trustworthy local collaborators, although the founders of these companies acknowledged the potential value of such an alliance. When cultural chasms between impact sourcing entrepreneurs and the community are too big, collaborative arrangements with (say) a local NGO may be an imperative for impact sourcing companies to operate successfully. Alliance partners can help impact sourcing companies span difficult socio-cultural boundaries. A collaborative entity strongly embedded in the community is likely to possess the cultural intelligence required to successfully tackle potentially tricky subjects, on behalf of impact sourcing companies (e.g., the recruitment of women employees), without offending local sensibilities.

\section{Outsourcing as a tool to achieve social innovation}

Impact sourcing is an emerging phenomenon, whose proponents aspire to achieve social innovation through outsourcing. In this paper, we have analyzed the entrepreneurial journeys of seven Indian impact sourcing companies. Our analysis also highlights the key challenges impact sourcing companies face in building and operating their companies. With businesses coming under increased scrutiny for their lackadaisical approach to social responsibility (Porter and Kramer, 2011), impact sourcing appears a good bandwagon to jump on for companies. It potentially showcases them globally as being committed to ethical and socially responsible strategies. In fact, thanks to the enthusiasm of management consultancy firms the scope of the term 'impact sourcing' itself has become much wider now with even global MNCs being seen as direct employers of offshore 'impact workers' (see Appendix B). In some ways, this broadening of perspective is important because it shows how outsourcing has a real positive impact on the lives of people in the developing world. The recent Everest Group (2014) report estimates that there are 235,000 direct beneficiaries of impact sourcing (i.e., impact sourcing employees) in the world. By contrast, impact sourcing companies in India -the empirical focus of this paper - in total employ only around 
9000 people, although a case can be made for how this type of a sourcing model is closer in spirit to the idea of impact sourcing as the bringing of digitally-enabled outsourcing jobs to marginalized individuals.

Put differently, bringing a diverse range of (already well-established) outsourcing scenarios under the impact sourcing umbrella can lead to a situation where almost any offshore outsourcing activity may be viewed as a case of impact sourcing. This line of argument could take the focus away from the impressive strides made by smaller impact sourcing companies to help historically disadvantaged and socially-excluded communities join the global economy through outsourcing. As highlighted in our study, such impact sourcing companies are achieving social innovation through a series of difficult maneuvers and complex actions, some of which are directed at local communities, others at potential clients and investors. It appears that the long-term sustainability of many these companies hinge not only on market conditions, but also on the degree to which the founders stay committed to impact sourcing. As one informant told us 'After all, they can throw it all away and go back to their cushy jobs anytime they want'. Given the impact sourcing model's potential to create social value, in conclusion, we would argue that industry bodies and national governments must play a much more proactive role to help impact sourcing companies develop new skills and knowledge, organize as a collective and gain access to business opportunity-enhancing networks.

\section{REFERENCES}

Accenture, 2011. Exploring the value proposition for Impact Sourcing: A Buyer's perspective. [pdf] Available at: http://www.accenture.com/SiteCollectionDocuments /PDF/Accenture-Exploring-Value-Proposition-Impact-Sourcing.pdf [Accessed 14th September 2014].

Ahn, H.K., Kim, H.J., Aggarwal, P., 2013. Helping fellow beings: anthropomorphized social causes and the role of anticipatory guilt. Psychological Science 25, 224-229. 
Aldrich, H.C., Fiol, C.M., 1994. Fools rush in? the institutional context of industry creation. Academy of Management Review 19, 645-670.

Apte, U.M., Mason, R.O., 1995. Global disaggregation of information-intensive services. Management Science 41, 1250-1263.

Battilana, J., Dorado, S., 2010. Building sustainable hybrid organizations: the case of commercial microfinance institutions. Academy of Management Journal 6, 1419-1440.

Battilana, J., Pache, A.C., Sengul, M., Model, J., 2012. Combining social welfare and market logics: what drives social performance in socio-economic hybrids? In The Academy of Management. The $72^{\text {nd }}$ Annual Meeting of the Academy of Management, Boston, USA, 2012.

Batstone, D., 2013. Impact Sourcing: a critical path for social change. [WWW] Available at: http://www.ssireview.org/blog/entry/impact_sourcing_a_critical_path_for_social_change [Accessed 4 March 2015].

BBC, 2011. Start-up stories: $N$ R Narayana Murthy, Infosys [WWW] Available at: http://www.bbc.co.uk/news/business-12957104 [Accessed 10 May 2014].

Brown, J.M., 1974. Gandhi's rise to power: Indian politics 1914-1922. Cambridge University Press, Cambridge.

Carmel, E., Lacity, M., Doty, A., 2013. The impact of Impact Sourcing: framing a research agenda. $4^{\text {th }}$ International Conference on the Outsourcing of Information Services, Mannheim, Germany.

Choi, N., Majumdar, S., 2014. Social entrepreneurship as an essentially contested concept: opening a new avenue for systematic future research. Journal of Business Venturing 29, 363376.

Contractor, F.J., Kumar, V., Kundu, S.K., Pedersen, T., 2010. Reconceptualizing the firm in a world of outsourcing and offshoring: the organizational and geographical relocation of highvalue company functions. Journal of Management Studies 47, 1417-1433.

Corner, P.D., Ho, M., 2010. How opportunities develop in social entrepreneurship. Entrepreneurship: Theory and Practice 34, 635-699.

Dacin, M.T., Dacin, P.A., Tracey, P., 2011. Social entrepreneurship: a critique and future directions. Organization Science 22, 1203-1213.

Dees, J. G., 1998. The meaning of social entrepreneurship. [pdf] Available at: http://csi.gsb.stanford.edu/sites/csi.gsb.stanford.edu/files/TheMeaningofsocialEntrepreneursh ip.pdf [Accessed January 2, 2015].

Everest Group, 2014. The case for impact sourcing. [pdf] Available at: http://www.everestgrp.com/wp-content/uploads/2014/09/RF-The-Case-for-Impact-SourcingFinal-approved_vf.pdf [Accessed 20 March 2014] 
Friedman, T.L., 2004. Thomas L. Friedman reporting: the other side of outsourcing. [video online] Available at: http://vimeo.com/14287759 [Accessed 14 May 2015].

Gino, F., Staats, B.R., 2012. The microwork solution. Harvard Business Review 90, 92-96.

Goffman, E., 1974. Frame analysis: An essay on the organization of experience, Harper and Row, New York.

Goffman, E., 1959. The presentation of self in everyday life. Doubleday, New York.

Heeks, R., 2013. Information technology impact sourcing. Communications of the ACM 56, 22-25.

Heeks, R., Arun, S., 2010. Social outsourcing as a development tool: the impact of outsourcing IT services to women's social enterprises in Kerala. Journal of International Development 22, 441-454.

Hindu, 2014. Only creation of jobs can stub poverty. [WWW] Available at: http://www.thehindu.com/news/cities/Mangalore/only-creation-of-jobs-can-stub-out-povertymurthy/article5581404.ece [Accessed 13 May 2015]

Jack, S.L., Anderson, A.R., 2002. The effects of embeddedness on the entrepreneurial process. Journal of Business Venturing 17, 467-487.

Khanna, T., 2014. Contextual intelligence. Harvard Business Review 92, 58-68.

Lacity, M.C., Rottman, J.W., Carmel, E., 2014. Impact Sourcing: employing prison inmates to perform digitally-enabled business services. Communications of the Association for Information Systems 34, 913-932.

Madon, S., Sharanappa, S., 2013. Social IT sourcing and development: theorizing the linkage. Information Systems Journal 23, 381-399.

Maguire, S., Hardy, C., Lawrence, T.B., 2004. Institutional entrepreneurship in emerging fields: HIV/AIDS treatment in Canada. Academy of Management Journal 47, 657-679.

Mair, J., Marti, I., 2006. Social entrepreneurship research: a source of explanation, prediction and delight. Journal of World Business 41, 36-44.

Malik, F., Nicholson, B., Morgan, S., 2013. Assessing the social development potential of impact sourcing. Proceedings of the $6^{\text {th }}$ Annual Conference SIG GlobDev, Milan, Italy.

Miller, T.Y., Grimes, M.G., McMullen, J.S., Vogus, T.J., 2012. Venturing for others with heat and head: how compassion encourages social entrepreneurship. Academy of Management Review 37, 616-640.

Monitor, 2011. Job creation through the field of Impact sourcing. [pdf] Available at: http://www.rockefellerfoundation.org/blog/job-creation-through-building-field [Accessed 16 October 2014]. 
Montgomery, A.W, Dacin, P.A., Dacin, M.T., 2012. Collective social entrepreneurship: collaboratively shaping social good. Journal of Business Ethics 111, 375-388.

Myers, M.D., 1997. Qualitative research in information systems. MIS Quarterly 21, 241-242.

NASSCOM, 2014. Next generation outsourcing: Opportunities through impact sourcing. [pdf] Available at:

https://www.nasscomfoundation.org/images/resources/2014_Report_on_Impact_Sourcing.pd f [Accessed 1 February 2015]

Pache, A.C., Santos, F., 2013. Inside the hybrid organization: selective coupling as a response to competing institutional logics. Academy of Management Journal 56, 972-1001.

Perrini, F., Vurro, C., Costanzo, L.A., 2010. A process-based view of social entrepreneurship: from opportunity identification to scaling up social change in the case of San Patrignano. Entrepreneurship and Regional Development 22, 515-534.

Pettigrew, A.M., 1990. Longitudinal field research on change: theory and practice. Organization Science 1, 267-292.

Porter, M., Kramer, M., 2011. Creating shared value, Harvard Business Review 89, 63-77.

Ravishankar, M.N., Pan, S.L., Myers, M.D., 2013. Information technology offshoring in India: a postcolonial perspective. European Journal of Information Systems 22, 387-402.

Renko, M., 2013. Early challenges of nascent social entrepreneurs. Entrepreneurship: Theory and Practice 37, 1045-1069.

Robinson, J., 2006. Navigating social and institutional barriers to markets: how social entrepreneurs identify and evaluate opportunities. In J. Mair, J. Robinson, \& K. Hockerts (Eds.), Social entrepreneurship (pp. 95-120). New York: Palgrave Macmillan.

Sarasvathy, S., 2001. Toward causation and effectuation : a theoretical shift from inevitability to economic entrepreneurial contingency. Academy of Management Review 26, 243-263.

Sandeep, M.S., Ravishankar, M.N., 2015. Impact sourcing ventures and local communities: a frame alignment perspective. Information Systems Journal, in press, DOI: 10.1111/isj.12057.

Sinkovics, N., Sinkovics, R.R., Yamin, M., 2014. The role of social value creation in business model formulation at the bottom of the pyramid - implications for MNEs? International Business Review 23, 692-707.

Smith, W.K., Besharov, M, Wessels, A., Chertok, M., 2012. A paradoxical leadership model for social entrepreneurs: challenges, leadership skills, and pedagogical tools for managing social and commercial demands. Academy of Management Learning \& Education 11, 463478.

Snow, D.A., Rochford JR., E.B., Worden, S.K., Benford, R.D., 1986. Frame alignment processes, micromobilization, and movement participation. American Sociological Review 51, 464-481. 
Spear, R., 2006. Social entrepreneurship: a different model? International Journal of Social Economics 33, 399 - 410.

Subbu, R., 2015. Govt. finalizing plan for call centers in mofussil towns: Ravi Shankar Prasad. [WWW] Available at: http://www.thehindu.com/business/Industry/govt-finalisingplan-for-call-centres-in-mofussil-towns-ravi-shankar/article6883783.ece [Accessed 3 March 2015].

Svendsen, A. C., Laberge, M., 2005. Convening stakeholder networks: a new way of thinking, being and engaging. Journal of Corporate Citizenship 19, 91-104.

VanSandt, C., Sud, M., Marme, C., 2009. Enabling the original intent: catalysts for social entrepreneurship. Journal of Business Ethics 90, 419-428.

Vestring, T., Rouse, T., Reinert, U., Varma, S., 2005. Making the move to low-cost countries. [pdf] Available at: http://bain.com/Images/BB_Making_move_low-cost_countries.pdf [Accessed 10 May 2014].

Walsham, G., 1995. The emergence of interpretivism in IS research. Information Systems Research 4, 376-394.

Yunus, M. 2010. Building social business: The new kind of capitalism that serves humanity's most pressing needs. Public Affairs, New York. 


\section{Appendix A: Organizations engaged in Impact Sourcing}

Organizations using impact sourcing include large global multinational corporations (e.g., Microsoft), traditional IT-BPOs (e.g., Infosys), focused impact sourcing companies (e.g., Digital Divide Data) and intermediaries (e.g. Samasource). The table below has been compiled using insights from the Everest Group report (Everest Group, 2014, p.28) on impact sourcing.

\begin{tabular}{|c|c|c|}
\hline Global MNCs & $\begin{array}{l}\text { - hire marginalized individuals directly as part of their } \\
\text { workforce. }\end{array}$ & $\begin{array}{l}\text { - Microsoft, Standard Bank, } \\
\text { Metropolitan Health }\end{array}$ \\
\hline Traditional IT-BPOs & $\begin{array}{l}\text { - hire marginalized individuals either directly or use impact } \\
\text { sourcing companies for servicing clients (through sub- } \\
\text { contracting). }\end{array}$ & $\begin{array}{ll}\text { - } & \text { Teleperformance } \\
\text { - } & \text { Infosys } \\
\text { - } & \text { Fullcircle } \\
\text { - } & \text { Aegis } \\
\text { - } & \text { Serco }\end{array}$ \\
\hline $\begin{array}{l}\text { Impact sourcing } \\
\text { companies }\end{array}$ & $\begin{array}{l}\text { hire and train marginalized individuals. Provide outsourcing } \\
\text { services directly to clients, traditional IT-BPOs and to } \\
\text { intermediaries (as described below). }\end{array}$ & $\begin{array}{ll}\text { - } & \text { DDD } \\
\text { - } & \text { Cloudfactory } \\
\text { - } & \text { SimplyGrameen }\end{array}$ \\
\hline Intermediaries & $\begin{array}{l}\text { - act as intermediaries between clients and providers (typically } \\
\text { other impact sourcing companies) of outsourcing services. } \\
\text { Some intermediaries are also impact sourcing companies } \\
\text { themselves. }\end{array}$ & $\begin{array}{l}\text { - } \quad \text { Samasource } \\
\text { - Head Held High }\end{array}$ \\
\hline
\end{tabular}


Appendix B: Overview of the seven cases

\begin{tabular}{|c|c|c|c|c|c|c|c|}
\hline & Company A & Company B & Company C & Company D & Company E & Company F & Company G \\
\hline $\begin{array}{l}\text { Company } \\
\text { details }\end{array}$ & $\begin{array}{l}\text { Vendor-owned, } \\
\text { founded in } \\
\text { 2009; Centers } \\
\text { in north India }\end{array}$ & $\begin{array}{l}\text { Vendor-owned } \\
\text { and operated by } \\
\text { franchises, } \\
\text { founded in 2007; } \\
\text { centers all over } \\
\text { India }\end{array}$ & $\begin{array}{l}\text { Vendor-owned, } \\
\text { founded in } \\
\text { 2010; centers in } \\
\text { south India }\end{array}$ & $\begin{array}{l}\text { Operated by } \\
\text { franchise, founded } \\
\text { in 2008; centers in } \\
\text { south India }\end{array}$ & $\begin{array}{l}\text { Vendor- } \\
\text { owned, } \\
\text { founded in } \\
2012 ; \\
\text { centers in } \\
\text { north India }\end{array}$ & $\begin{array}{l}\text { Vendor- } \\
\text { owned, } \\
\text { founded in } \\
\text { 2007; centers } \\
\text { in south India }\end{array}$ & $\begin{array}{l}\text { Vendor- } \\
\text { owned, } \\
\text { founded in } \\
\text { 2007; centers } \\
\text { in south India }\end{array}$ \\
\hline $\begin{array}{l}\text { Nature of } \\
\text { ownership \& } \\
\text { funding }\end{array}$ & $\begin{array}{l}\text { For-profit; } \\
\text { funded by } \\
\text { social venture } \\
\text { capital }\end{array}$ & $\begin{array}{l}\text { For-profit; funded } \\
\text { by social venture } \\
\text { capital; few } \\
\text { centers financially } \\
\text { supported by the } \\
\text { provincial } \\
\text { government }\end{array}$ & $\begin{array}{l}\text { For-profit; } \\
\text { private equity }\end{array}$ & $\begin{array}{l}\text { For-profit; private } \\
\text { equity }\end{array}$ & $\begin{array}{l}\text { For-profit; } \\
\text { private } \\
\text { equity }\end{array}$ & $\begin{array}{l}\text { For-profit; } \\
\text { funded by } \\
\text { social venture } \\
\text { capital }\end{array}$ & $\begin{array}{l}\text { For-profit; } \\
\text { private equity }\end{array}$ \\
\hline $\begin{array}{l}\text { What kind of } \\
\text { services do } \\
\text { they offer? }\end{array}$ & $\begin{array}{l}\text { XML tagging, } \\
\text { Creating } \\
\text { publishable } \\
\text { content, } \\
\text { Digitization, } \\
\text { Claims } \\
\text { processing, } \\
\text { XBRL, } \\
\text { managing } \\
\text { backend } \\
\text { processes for } \\
\text { different } \\
\text { functions }\end{array}$ & $\begin{array}{l}\text { Software testing, } \\
\text { voice-based } \\
\text { services, Social } \\
\text { marketing, Data } \\
\text { processing, } \\
\text { Digitization, } \\
\text { managing backend } \\
\text { processes for } \\
\text { different functions }\end{array}$ & $\begin{array}{l}\text { Digitization, } \\
\text { web-content } \\
\text { management, } \\
\text { managing } \\
\text { backend } \\
\text { processes for } \\
\text { different } \\
\text { functions }\end{array}$ & $\begin{array}{l}\text { Web-testing, } \\
\text { software testing, } \\
\text { tech support, } \\
\text { digitization, social } \\
\text { media analytics, } \\
\text { quality testing, } \\
\text { backend process for } \\
\text { banking and } \\
\text { finance, computer } \\
\text { aided design }\end{array}$ & $\begin{array}{l}\text { Image } \\
\text { tagging, } \\
\text { digitization } \\
\text { of content, } \\
\text { voice based } \\
\text { support, } \\
\text { transcription } \\
\text { services }\end{array}$ & $\begin{array}{l}\text { Data entry, } \\
\text { digitization, } \\
\text { Web-testing, } \\
\text { content } \\
\text { management, } \\
\text { customer } \\
\text { support }\end{array}$ & $\begin{array}{l}\text { Managing } \\
\text { backend } \\
\text { processes of } \\
\text { banking and } \\
\text { finance } \\
\text { services }\end{array}$ \\
\hline $\begin{array}{l}\text { Who are the } \\
\text { typical } \\
\text { clients? }\end{array}$ & $\begin{array}{l}\text { Traditional IT- } \\
\text { BPO } \\
\text { companies in } \\
\text { India; small }\end{array}$ & \begin{tabular}{|l} 
Traditional IT- \\
BPO companies in \\
India, Large \\
Multinational
\end{tabular} & $\begin{array}{l}\text { Traditional IT- } \\
\text { BPO companies } \\
\text { in India }\end{array}$ & $\begin{array}{l}\text { Traditional IT-BPO } \\
\text { companies in India, } \\
\text { small and medium } \\
\text { companies, both in }\end{array}$ & $\begin{array}{l}\text { Small and } \\
\text { medium } \\
\text { companies, } \\
\text { both in India }\end{array}$ & $\begin{array}{l}\text { Traditional IT- } \\
\text { BPO } \\
\text { companies in } \\
\text { India, Large }\end{array}$ & $\begin{array}{l}\text { Medium and } \\
\text { Indian } \\
\text { companies }\end{array}$ \\
\hline
\end{tabular}




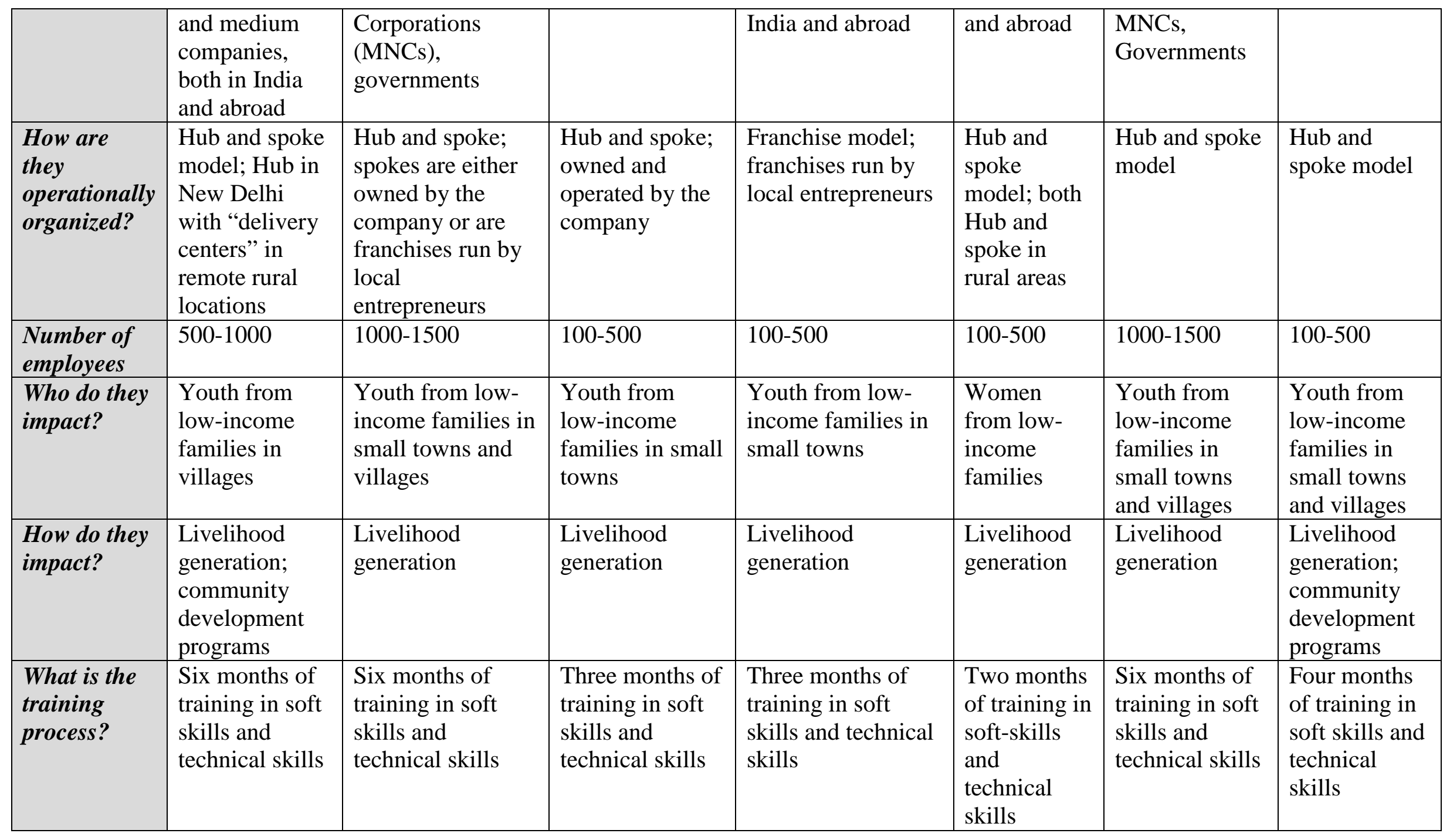




\section{Appendix C: Overview of informants}

\begin{tabular}{|c|c|c|c|}
\hline $\begin{array}{l}\text { Impact } \\
\text { sourcing } \\
\text { company }\end{array}$ & Designation of the Informant & $\begin{array}{l}\text { No. of } \\
\text { Interviews }\end{array}$ & $\begin{array}{c}\text { Total No. } \\
\text { of } \\
\text { Interviews }\end{array}$ \\
\hline \multirow{6}{*}{ Company A } & Chief Executive Officer (CEO)/Co-Founder & 4 & \multirow{6}{*}{20} \\
\hline & Co-Founder & 2 & \\
\hline & Business Development Manager (BDM) & 2 & \\
\hline & Chief Technology Officer (CTO) & 3 & \\
\hline & Centre Manager & 4 & \\
\hline & Team Leader & 5 & \\
\hline \multirow{8}{*}{ Company B } & Chief Executive Officer (CEO)/Co-Founder & 1 & \multirow{8}{*}{10} \\
\hline & Chief Technology Officer (CTO) & 1 & \\
\hline & Business Development Manager (BDM) & 1 & \\
\hline & $\begin{array}{l}\text { Associate Vice-President- Human Resources } \\
\text { (AVP-HR) }\end{array}$ & 1 & \\
\hline & Manager (HR) & 1 & \\
\hline & Marketing & 1 & \\
\hline & Centre Manager & 1 & \\
\hline & Team Leader & 3 & \\
\hline \multirow{3}{*}{ Company C } & CEO/Founder & 1 & \multirow{3}{*}{6} \\
\hline & Chief Operating Officer (COO) & 1 & \\
\hline & Team Leader & 4 & \\
\hline \multirow{4}{*}{ Company D } & CEO/Co-Founder & 1 & \multirow{4}{*}{6} \\
\hline & Centre Manager & 2 & \\
\hline & Manager - Training & 1 & \\
\hline & Team Leader & 2 & \\
\hline \multirow{2}{*}{ Company E } & Managing Director/Founder & 1 & \multirow{2}{*}{2} \\
\hline & Executive Director/Co-founder & 1 & \\
\hline \multirow{2}{*}{ Company F } & CEO/Founder & 1 & \multirow{2}{*}{2} \\
\hline & Business Development Manager & 1 & \\
\hline Company G & Co-Founder/CEO & 2 & 2 \\
\hline & & Total & 48 \\
\hline
\end{tabular}




\section{Appendix D: Interview protocol}

\section{Sample interview guide}

\section{a. For the Founders of impact sourcing companies}

1. Can you please talk about your professional life so far?

2. When did you start considering changing careers?

a. Were there any critical incidents that made a difference? How did they influence you?

3. How did you start developing this idea? What were your motivations?

a. Did you consider other options?

b. Why did you decide to stick with this option?

4. Did you have any doubts or apprehensions before starting the venture?

a. How did you deal with them? How were you convinced?

5. How was the shift from being an employee to an entrepreneur?

a. What challenges did you face in making this shift?

b. How did the reality stack up to your imagination?

6. Did you have to acquire new skills in this process? Can you give examples?

a. How did you go about doing this?

7. What were the major challenges that you faced in the first year?

8. Overall, how has the past year been?

9. What is your typical sales pitch when you are meeting investors?

10. How do you convince clients about the value proposition?

11. Where do you see this organization five years from now?

a. What challenges are you anticipating?

12. How have your goals and aspirations changed over the past few years?

13. What in your opinion is the future of impact sourcing?

\section{b. For the Senior Management of impact sourcing companies (Business development/Marketing)}

1. Can you please talk about your professional life so far?

2. What were your motivations to join this company?

3. How has your experience been so far?

a. How is it different from you previous work?

4. What is your typical sales pitch?

5. How do you convince clients about the viability of the relationship?

a. What according to you are some of the key advantages and disadvantages of the impact sourcing model?

6. Where do you see this organization five years from now?

a. What challenges are you anticipating?

7. What in your opinion is the future of impact sourcing? 


\section{c. For the Senior Management of Impact sourcing companies (Centre Managers/Operations)}

1. Can you please talk about your professional life so far?

2. What were your motivations to join this company?

3. How has your experience been so far?

a. How is it different from you previous work?

4. What are the typical challenges of managing a center?

a. How do you work around these challenges?

5. Where do you see this organization five years from now?

a. What challenges are you anticipating?

\section{d. For NASSCOM Foundation (NF)}

1. How did NF get involved in impact sourcing?

2. How would you describe NF's role in impact sourcing?

3. What are the main activities of NF?

a. What were the major challenges?

4. What is your outlook for the Impact sourcing model in India?

a. What do you see as the main enablers and impediments of impact sourcing in India? 